\title{
JAMWA RAMGARH RESERVOIR: STATUS AND FUTURE PROSPECTS
}

\author{
Kumari Anamika1, M. P. Punia ${ }^{2}$ and Chilka Sharma ${ }^{1}$ \\ 1Department of Earth Sciences, Banasthali Vidyapeeth, Newai, Rajasthan, India \\ ${ }^{2}$ Head, Department of Remote Sensing, Birla Institute of Scientific Research, Jaipur, India \\ Email: ana.mika7026@gmail.com, punia.rsd@gmail.com
}

How to cite this paper:

Anamika Kumari, Punia, M.P., and Sharma, Chilka (2021) Jamwa Ramgarh Reservoir: Status and future prospects, Journal of Global Resources, Vol. 07 (02)

DOI:

10.46587/JGR.2021.v07i02.001

Received: 21 March 2021 Reviewed: 10 April 2021 Revised: 11 May 2021

Final Accepted: 27 May 2021

\section{OPEN O A C E S S} Freely available Online
www.isdesr.org

\begin{abstract}
Urbanization and industrialization have increased size of habitations, and accordingly water requirements also increased. Rajasthan being located in semi-arid area have severe problems of water supply to most of the towns including capital town Jaipur. Initial source water was provided through tanks, Ponds, Baorietc constructed. As population and development happened, it was started from Jamwa-Ramgarh, which is 25 kilometers away from Jaipur city. After drying of Jamwa Ramgarh, government of Rajasthan started Banas water by constructing dam at Bisalpur and there is new plan to tape Himalaya's feed rivers through river linking or any other network of canals. But this process is not sustainable as there is limitation of technical, social issues for long distance transfer of water. The sustainable solution of this ever-increasing problem is rainwater harvesting, construction and scientific management of lakes, ponds etc. The present study is focused on Jamwa-Ramgarh reservoir, which was prime source of drinking water earlier, now dried up due to mismanagement and scope of revival of ecosystem its catchment as sustainable source of water. Earlier Ramgarh reservoir was major source of water supply to Jaipur city. After 1990 water supply from Ramgarh reservoir has reduced continuously due to unavailability of water in reservoir. At present dam remain operational only during rainy season and post rainy period (July - November). Using satellite data (IRS-LISS-III and Google Earth) and field investigations, 104 hydrological structures have been identified, which if reached to the Ramgarh reservoir can fill the reservoir up to $32 \mathrm{ft}$. height, and support Jaipur city in sustainable manner.
\end{abstract}

Keywords: Jamwa Ramgarh Reservoir, Canal Network, Banas River, Hydrological Structure 


\section{Introduction}

The primary source of water in the Rajasthan is precipitation. Rainfall in large parts of the state is inadequate and varies sharply every year. This results into draughts. Water flow in the state rivers is entirely dependent upon the incidence of rainfall. Rajasthan population growth rate is highest in the country. Water demand is increasing continuously because of, development, tourism and recreation Water supply has either remained unchanged or further reduced. Twothirds of the state suffers from recurrent water scarcity. Ramgarh Lake used to be the major source of water supply in Jaipur city, but due to some negligence and lack of proper management, and maintenance the lake is on the urge of dying. Ramgarh is an artificial lake created by constructing a dam across Banganga River. There are hills at both side of dam and have good storage space. The lake is situated at $25 \mathrm{Km}$. in northeast direction from Jaipur city, where the temple of Mata and the ruins of the old fort are some of its antiquities. It is good tourist spot for visitors.

\section{Study Area and its Characteristics}

The catchment area of Ramgarh Lake hosts variety of flora, fauna and geomorphic landforms, especially an undulating terrain with subdued relief merging into the alluvial tract drained by the river Banganga, which is the major contributory in Ramgarh Lake. The downward flow of river Banganga is in a sinusoidal fashion towards its destination i.e., the Ramgarh Lake, which covers approximately a distance of $59.81 \mathrm{kms}$.

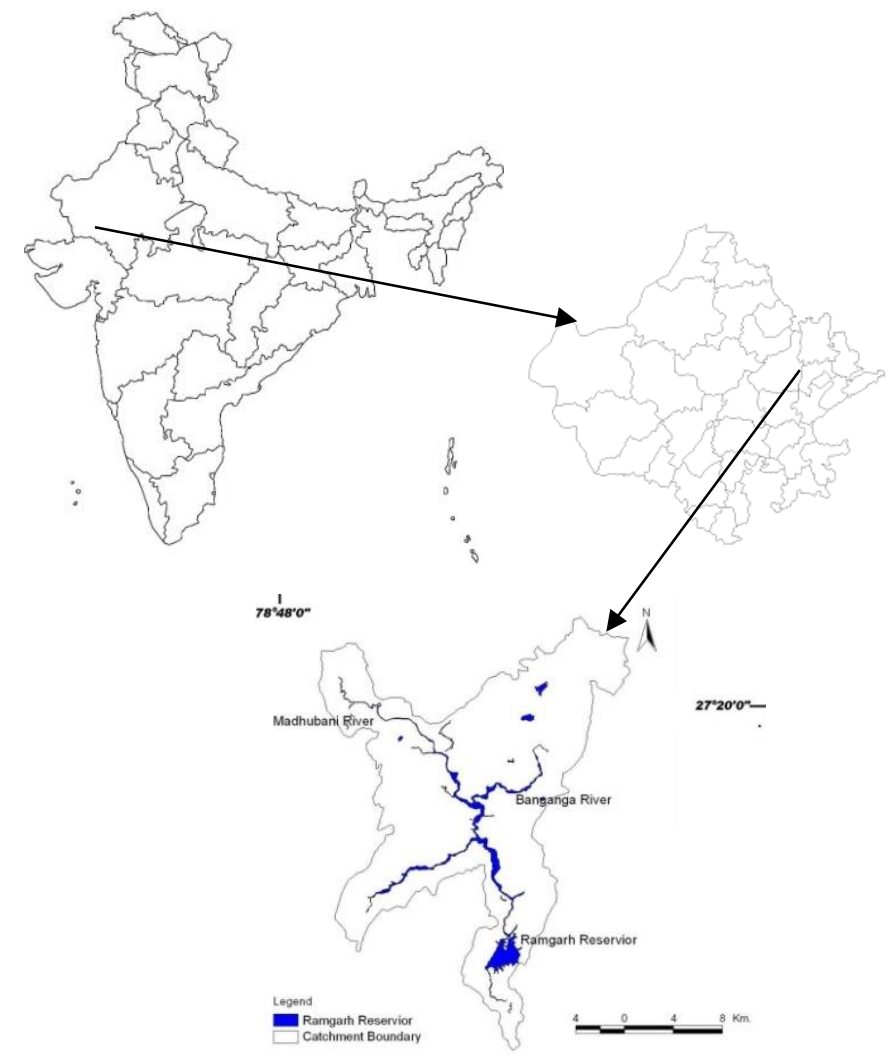

Figure 01: Location of the Study Area

\section{Climate}

The Ramgarh lake catchment has a semi-arid type of sub-tropical monsoon climate with dryhot summers, low scanty monsoon rains, and a cold winter season. The winter commences from October, Summer starts from middle of April and reach its peak in May-June, when average maximum temperature goes up to $40.6^{\circ} \mathrm{C}$ in May. 


\section{Rainfall}

Table 1. shows that most of the rainfall recorded at Ramgarh meteorological station is during the monsoon months i.e., from June to September, whereas, remaining part of the year remains dry or very less rainfall received. It is either due to mid latitudinal western disturbances or due to the local disturbances (fig2). Rainfall data of 21 years of Ramgarh station have been analyzed. Maximum rainfall is recorded in year $1996(1092.1 \mathrm{~mm})$ and minimum in year 1987 (286.1 mm) (Table 2).

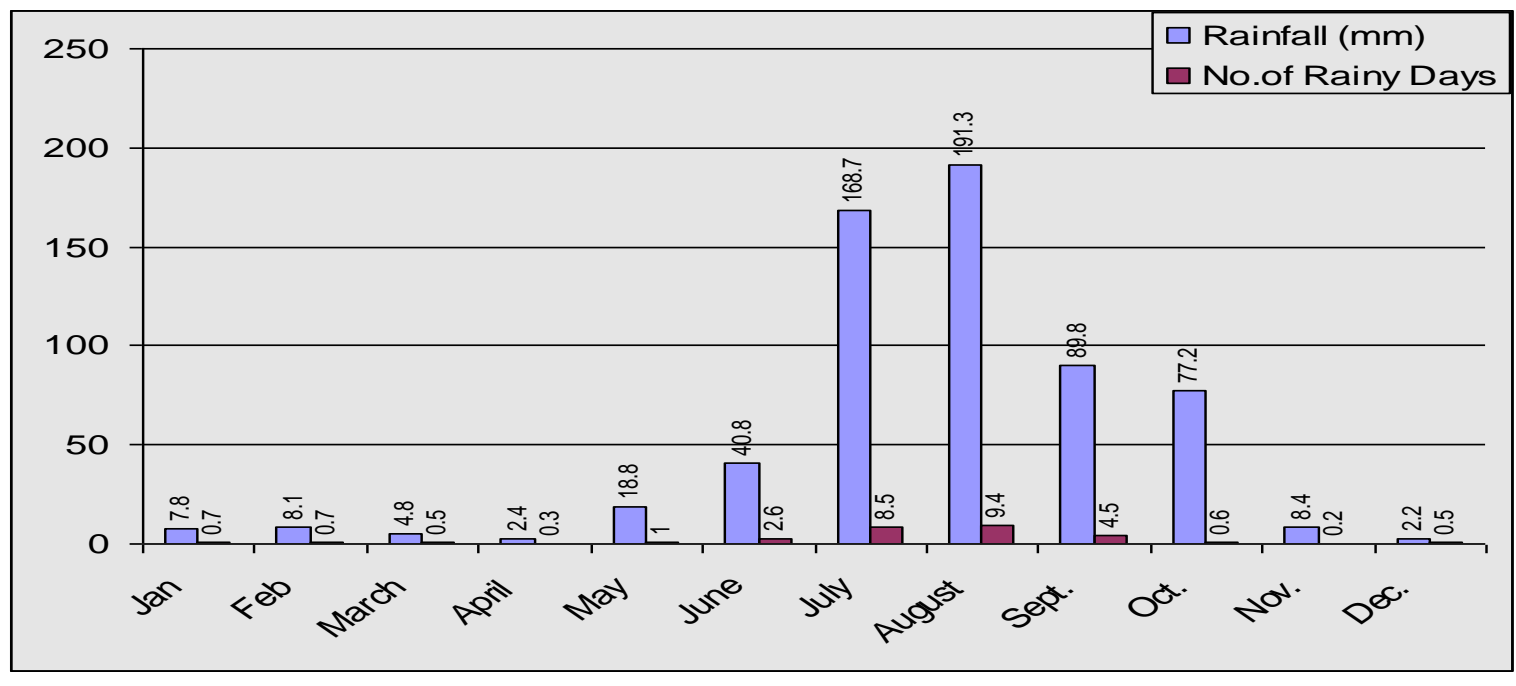

\begin{tabular}{|c|c|c|c|c|c|c|c|c|c|c|c|c|c|}
\hline YEAR & TAN & FEE & MLAR & APR & MAY & JUN & JULY & AUC & SEP & OCT & NOV & DEC & TotaI \\
\hline 1985 & o & o & o & 22 & o & 32.7 & 325.7 & 235 & 4 & 90.1 & o & 8.2 & 717.7 \\
\hline 1986 & o & 31.3 & o & o & 30.8 & 40.5 & 173.7 & 99.8 & 1 & 26.4 & o & o & 372.2 \\
\hline 1987 & 10 & 17 & 1 & o & 47.8 & 10 & 14.5 & 162.3 & 9 & o & o & 14.5 & 259.1 \\
\hline 1988 & 2.6 & 2.1 & 6.3 & o & 0 & 41.8 & 195.3 & 197.5 & 74.4 & o & o & o & 515.3 \\
\hline 1989 & 17.5 & $\circ$ & 0.5 & o & o & 48.5 & 137.7 & 223.9 & 7 & o & o & o & 417.6 \\
\hline 1990 & o & 37.6 & o & o & 1 & 79.5 & 1439 & 119.8 & 96.7 & o & 17.6 & o & 458.5 \\
\hline 1991 & o & 4 & o & o & 10 & 17 & 157.9 & 200.7 & 81.9 & o & o & 32 & 499.5 \\
\hline 1992 & 15 & $\circ$ & o & o & o & o & 275 & 291 & 87 & o & o & o & 653 \\
\hline 1993 & o & 19 & 7.2 & o & 0 & 147.5 & 233.4 & 35 & 68 & o & o & o & 491.1 \\
\hline 1994 & 17.2 & o & o & 5 & 0 & 82 & 199.8 & 130.8 & 53.4 & o & o & o & 471 \\
\hline 1995 & 26 & 12 & 5.5 & 0 & 2 & 5 & 235.2 & 575.7 & 35 & o & 0 & o & 858.4 \\
\hline 1996 & 9.8 & 8.8 & 3 & o & 21.5 & 162 & 168 & 289 & 374 & 56 & o & o & 1073.5 \\
\hline 1997 & o & o & 3 & 39 & 5 & 64 & 155.4 & 150 & 147.6 & 223 & 16 & 15.4 & 818.4 \\
\hline 1998 & o & 3 & 4 & o & o & 22 & 203 & 210 & 142 & 38 & o & o & 619 \\
\hline 1999 & 3 & 3 & o & o & o & 53 & 284 & 54 & 54 & o & $\circ$ & o & 445 \\
\hline 2000 & 0 & 0 & o & 0 & 10 & 54 & 308 & 177 & 20 & 0 & 0 & 0 & 569 \\
\hline 2001 & o & o & 4 & 3 & 33 & 115 & 90 & 161 & o & o & o & o & 406 \\
\hline 2002 & o & 5 & o & 4 & 28 & 27 & 38 & 190 & 14 & 0 & o & 35 & 336 \\
\hline 2003 & 1 & 62 & o & o & 8 & 195 & 435 & 212 & 154 & 1 & o & o & 1005 \\
\hline 2004 & $\circ$ & o & o & o & 66 & 91 & 164 & 426 & 39 & 275 & o & o & 1061 \\
\hline 2005 & o & 2 & 5 & 9 & 0 & 293 & 306 & 18 & 347 & o & o & o & 978 \\
\hline
\end{tabular}

Figure 02: Average Rainfall \& Rainy days in Jamwa-Ramgarh Catchment

\section{Temperature}

The average temperature during summer of the Ramgarh catchment is $21.6^{\circ} \mathrm{C}$ (table below). However, the mean monthly maximum of the region is $40.6^{\circ} \mathrm{C}$. (fig 3 )

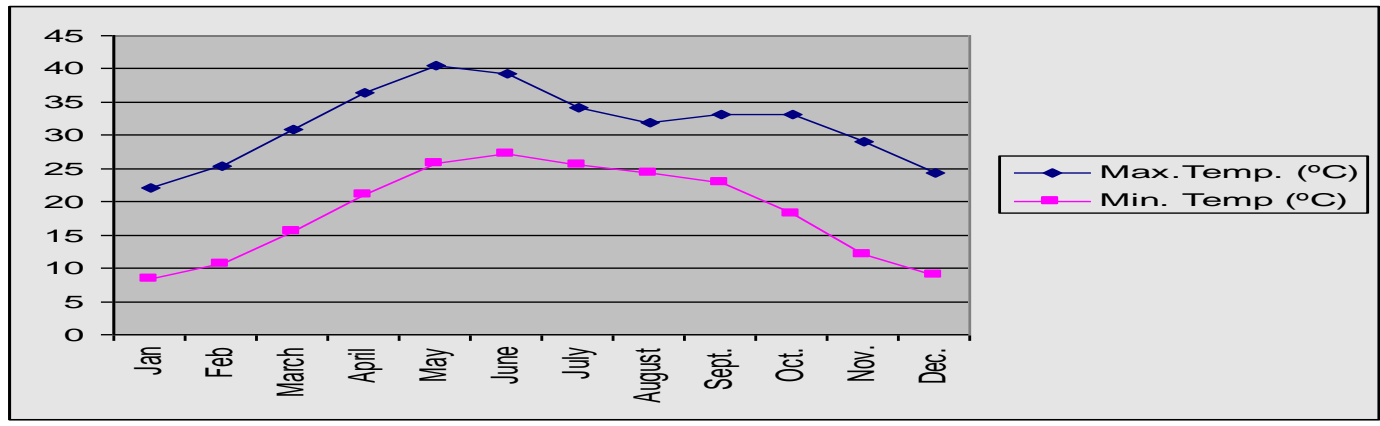

Figure 03: Mean Monthly Minimum and Maximum Temperature 


\section{Geology}

The basic data of Lithology, synthesized for the catchment area have been incorporated into Arc/Info vector layer (fig 4).

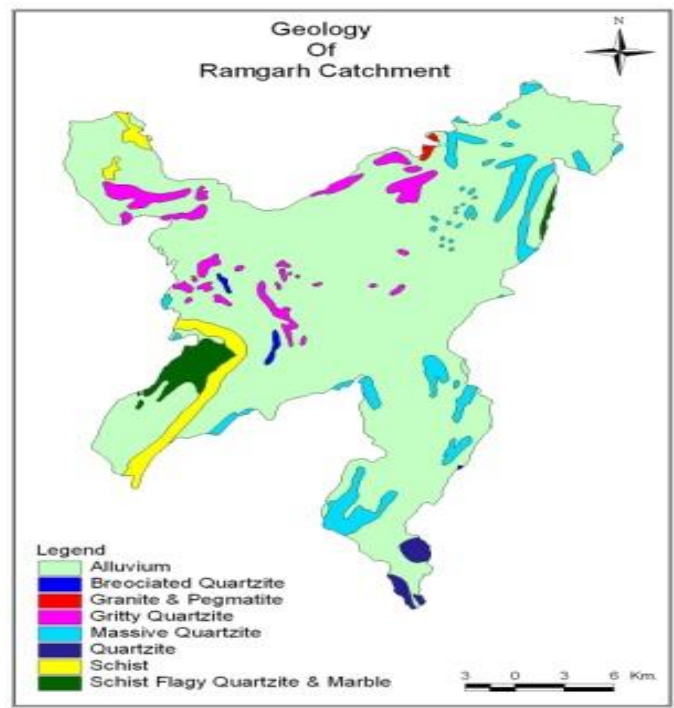

Figure 04: Geology of Study Area

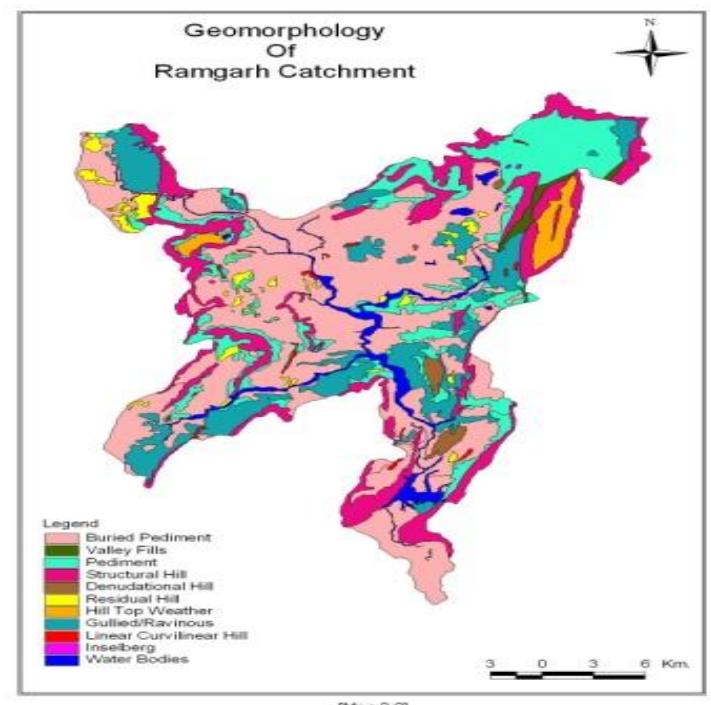

Figure 05: Geomorphology of Study area

\section{Geomorphology}

The landform divisions are based on the existing relief features, and provide a basis of the study of geomorphic evolution of the terrain which has been sculptured by a number of erosional cycles represented by various surfaces (Fig 5).

\section{Slope}

Slope plays very significant role in determining infiltration, and runoff in any watershed or catchment. Infiltration is inversely related to slope i.e., gentler the slope is, infiltration would be more and runoff would be less and vice-versa. The slope map has been created using DEM of study area while defining a cell size of 23.5 meters.

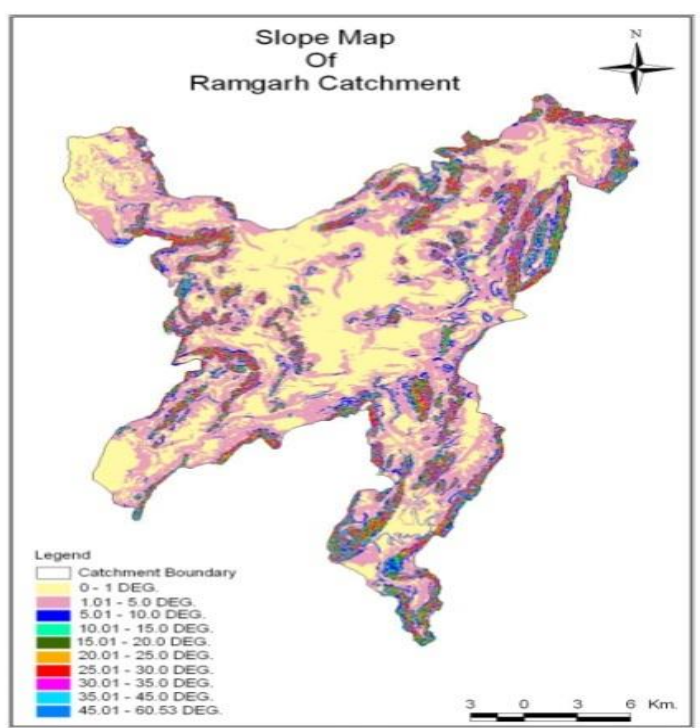

Figure 06: Slope Map



Figure 07: Digital Elevation Model

\section{Land use / Land Cover}

The supervised classification for Land use / land cover was done on IRS-ID LISS-III images for years 1996-97 and 2005-06 using maximum likelihood algorithm. Additionally, manual 
refinement has been done using available topographic maps and ground truth data that has been collected.

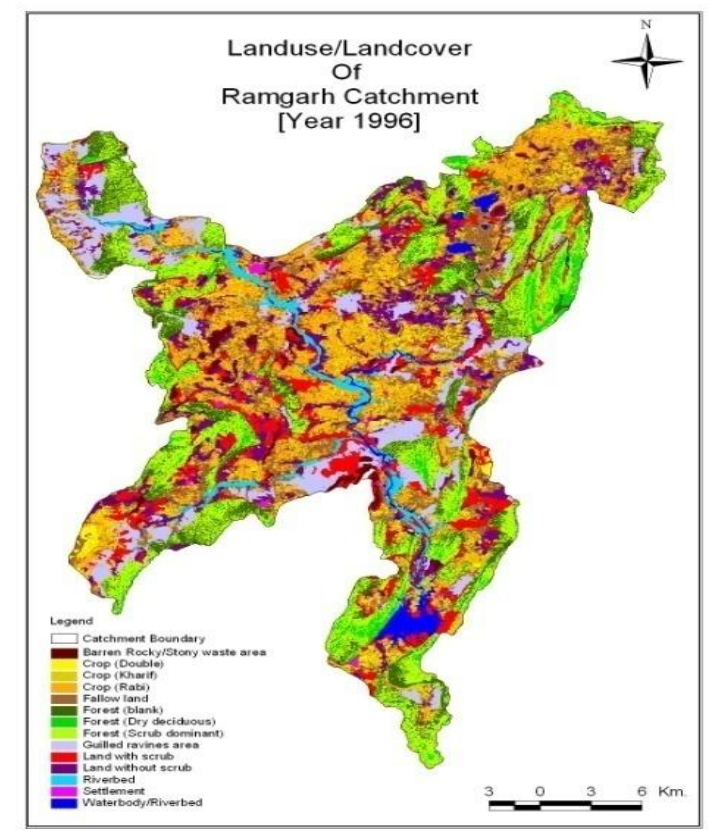

Figure 08: Land use/Land Cover, 1996

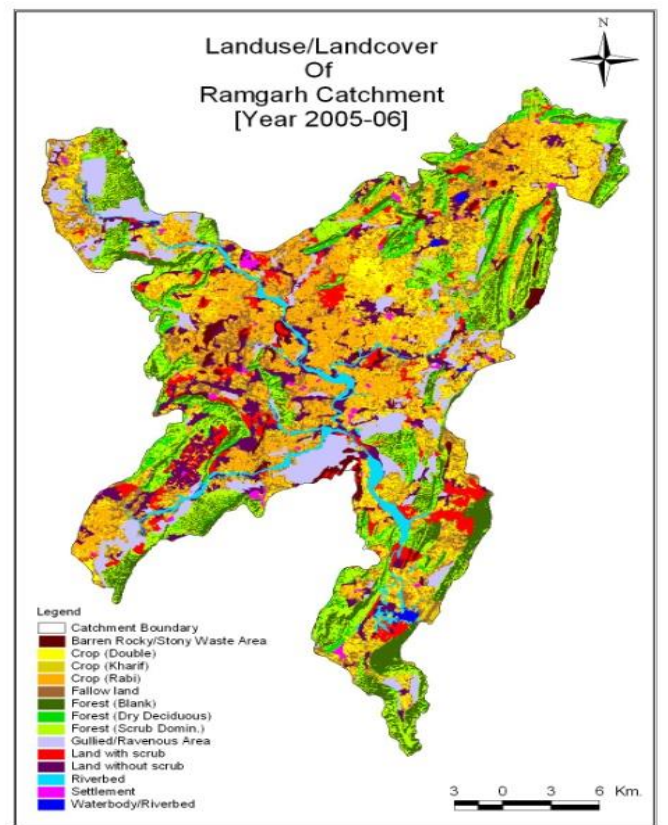

Figure 09: Land use/Land Cover, 2005-06

\section{Problem Statement}

Ramgarh reservoir which was the, prime source of water supply for Jaipur city has dried and is becoming a matter of prime concern. The statistics tells that the water supply is surprisingly reduced as 25 lac liter/day had been supplied against the supply of 425 lac liter/day initially. The water level on April 01, 2006 was R.L. 226 (26 feet) and its capacity was 44.60 Mcft. at the same level. The reservoir was almost dry on March 01, 2007. Thereafter Ramgarh reservoir is not getting any inflow, and dried completely.

\section{Objectives}

1. To identify and map the hydrological structures raised in the upper catchment of Ramgarh reservoir.

2. To access the possible effect of these hydrological structures on the storage and inflow parameters at Ramgarh reservoir.

3. To suggest possible interventions to restore the ecological status of reservoir and its catchment.

\section{Methodology}

Remote Sensing data of the years 1984 and 2005 were analyzed digitally to understand the patterns of land use / land cover, and changes occurred during this period. The secondary data pertaining to rainfall in the study area from 1984 to 2005, interception, transpiration, inflow, parameters effecting runoff, the river channels, storage capacity at various levels of Ramgarh dam, annual water supply from Ramgarh etc. were collected. Hydrological structures were identified on satellite images of IRS-LISS III images of Google Earth and by field visits. Measurement of length, width and depth of individual structures were measured physical on the ground, and calculated storage capacity of individual structures. Categorizations of hydrological structures have been done into major medium and minor as per their storage capacity. Catchments of individual structures have been demarcated on 1:50,000 toposheets and satellite images. Runoff from each catchment has been calculated as per the stranger's table method and compared with the storage capacity of individual structures to calculate 
effectiveness of structures in the way of flowing water. Total quantity of water being intervened by hydrological structures have been calculated by analyzing storage capacity and runoff generation from the catchments.

\section{Analysis}

To understand the drainage interrelationship morphometric parameter have been calculated at micro watershed level, by GIS this purpose remote sensing and GIS tools are used for drainage delineation and updation. Number and order of stream length, drainage density, stream frequency, bifurcation ratio, shape index, circulatory ratio have been calculated for water resource planning. The first order drainage has a frequency of 2.525 , highest amongst all. Although they lack the central part of the area, yet have a good association around, and at the marginal areas of hills and residual hills. During the field work, it has been found that the higher frequency of first order drainage give the villagers an idea for earthen dams constructed by soil, clay and stones at the hill slopes. These areas having high drainage frequency are the same with high drainage density and high run off producing areas. Maximum structures are constructed on these land and abstracting water outflow from these high runoff generating areas. The high frequency of these is probably due to the development of gullies and rills at the margins of hilly area where water strikes with a high velocity. The second order drainage has an average frequency of 1.197 formed due to the meeting of two first order drainage and well distributed all over the study area.

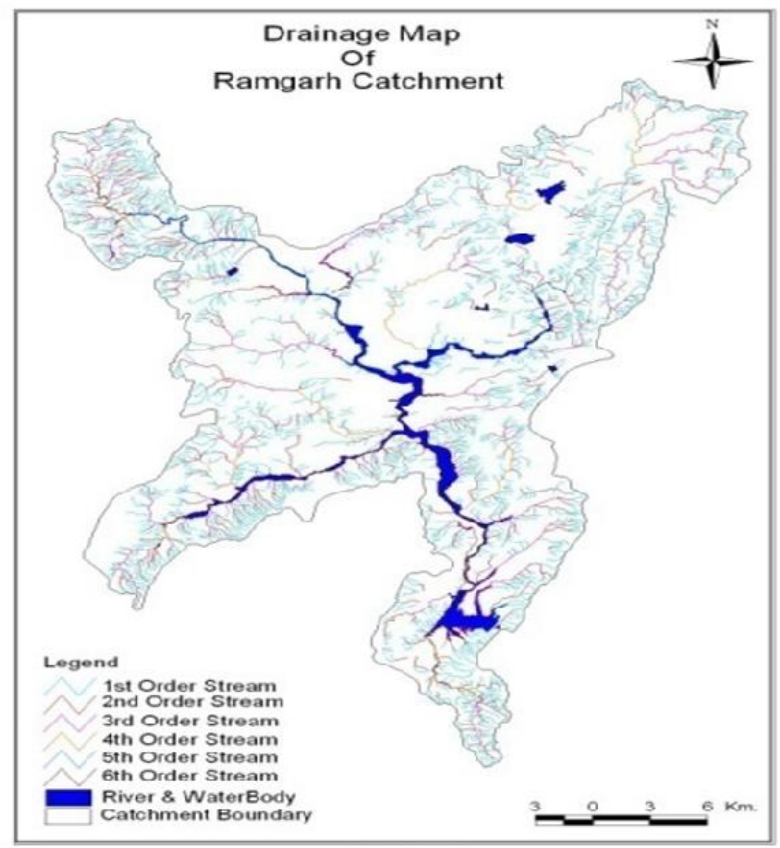

Figure 10: Drainage Density



Figure 11: Drainage Map

\section{Hydrological Structures}

The study area comprises 12 major hydrological structures, which have storage capacity of $5,000 \mathrm{~m}^{3}$. The total storage capacity of the major hydrological structure is $2334641.226 \mathrm{~m}^{3}$. Maximum storage capacity is found for hydrological structure (HS) no. 52 with storage capacity of $858593.75 \mathrm{~m}^{3}$ followed by $\mathrm{SH}$ no 104 with the storage capacity of 441773.438 . Minimum storage capacity is found for HS no.60 with storage capacity of $5102.5 \mathrm{~m}^{3}$ only. Whatever amount of water, comes and gets stored in these hydrological structures in the form of rainfall and runoff, gets intercepted in between and severely affect the amount of runoff, which reaches to fill the Ramgarh reservoir. There are 16 medium hydrological structures, with storage capacity ranging from $1000-5,000 \mathrm{~m}^{3}$. They collectively store total $35447.39 \mathrm{~m}^{3}$ of water. Apart 
from the above-mentioned categories, 76 minor structures have been found with storage capacity below $1000 \mathrm{~m}^{3}$. They collectively can store $19937.68 \mathrm{~m}^{3}$ water. Major, Medium and minor hydrological structures collectively can store $2390026.296 \mathrm{~m}^{3}$. Looking to the storage capacities, it is clear that contribution of medium and minor hydrological structures is quite insignificant and accounts for $1.46 \%$ and $0.08 \%$ of the total storage capacity. Major hydrological structures; restrict the maximum water to reach the Ramgarh reservoir.

The major structures vary widely in storage capacity. Maximum storage capacity is found as $858593.75 \& 441773.438 \mathrm{~m}^{3}$ for hydrological structure number $52 \& 104$ respectively. Minimum storage capacity is found as $5102.5 \mathrm{~m}^{3}$ for structure number 60 . These structures collectively can store $2334641.226 \mathrm{~m}^{3}$ of water.

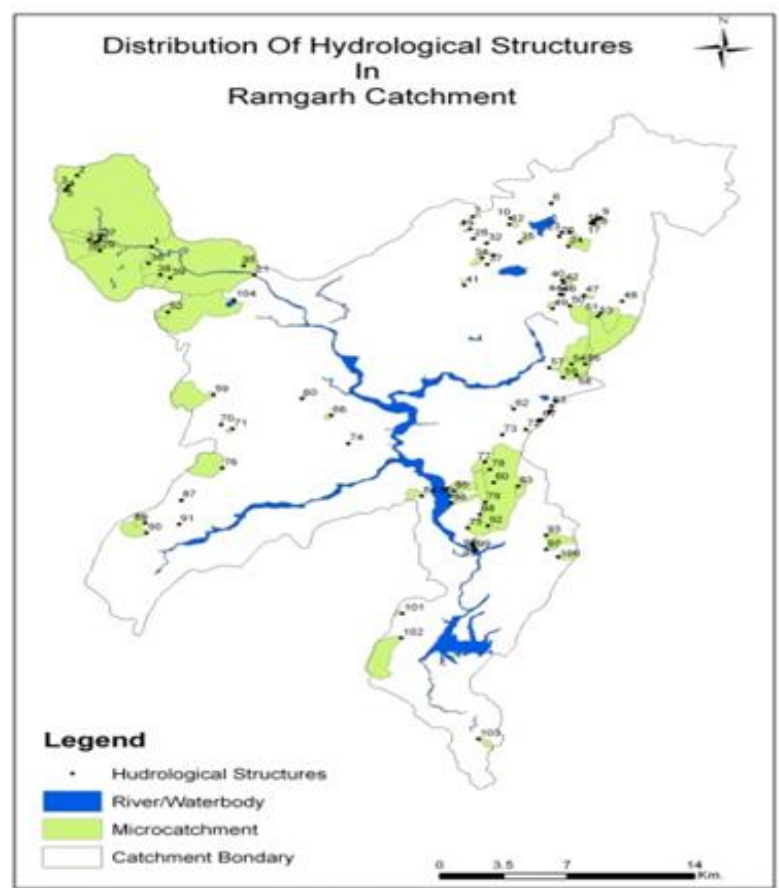

Figure 12: Hydrological Structure

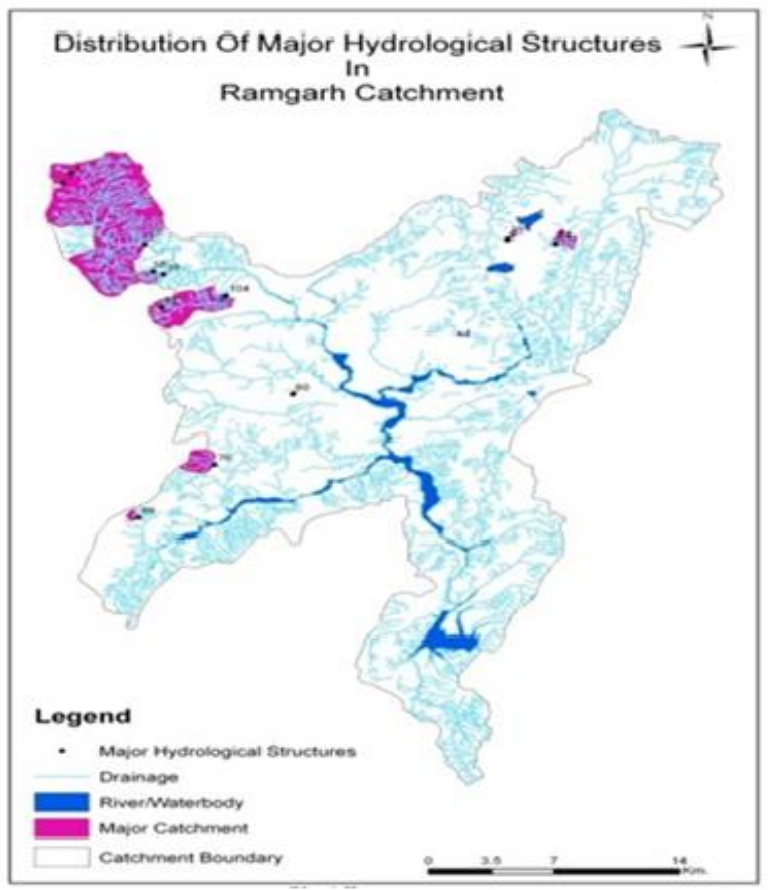

Figure 09: Major Hydrological Structure

\section{Estimation of Total Run-off}

For the study we used empirical equation method for calculation of Run-off. Study shows that storage capacity is not of the order of runoff generation from catchment areas. Some major hydrological structures are small than runoff Generation (HS No. 1, 76). Otherwise, hydrological structures are bigger than the estimated runoff. Storage capacity of all major hydrological structures is $2334641.226 \mathrm{~m}^{3}$ against the runoff Generation of $2259040.91 \mathrm{~m}^{3}$. One hydrological structure (HS no. 104) constructed across Madhubani river, has water throughout the year.

Imbalance between storage capacity and runoff Generation in case of medium hydrological structures is very high in compared to major structures. Total storage capacity of all the medium hydrological structures is $35447.39 \mathrm{~m}^{3}$ against the runoff $336662.289 \mathrm{~m}^{3}$. These structures are mainly constructed on second or third order streams which generally remain dry except in rainy days only and also for few hours. Therefore, the entire runoff is received during few rainy days only and after few days this accumulated water percolate down or evaporates. During rainy season these structures get water many times. Therefore, higher runoff accommodated in these smaller structures. Apart from these medium structures there are many very small earthen structures also constructed for the purpose of soil and water 
conservation, which store very small quantity of water (may few cubic meters) but are able to distribute flowing water into small water fills and effectively check the incoming water. This water percolate down or evaporate immediately in $2 / 3$ days because porosity of sandy soils is very high and the evaporation rates is also high. Therefore, a medium structure is able to catch more amount of runoff generated from catchment areas in many spaces.
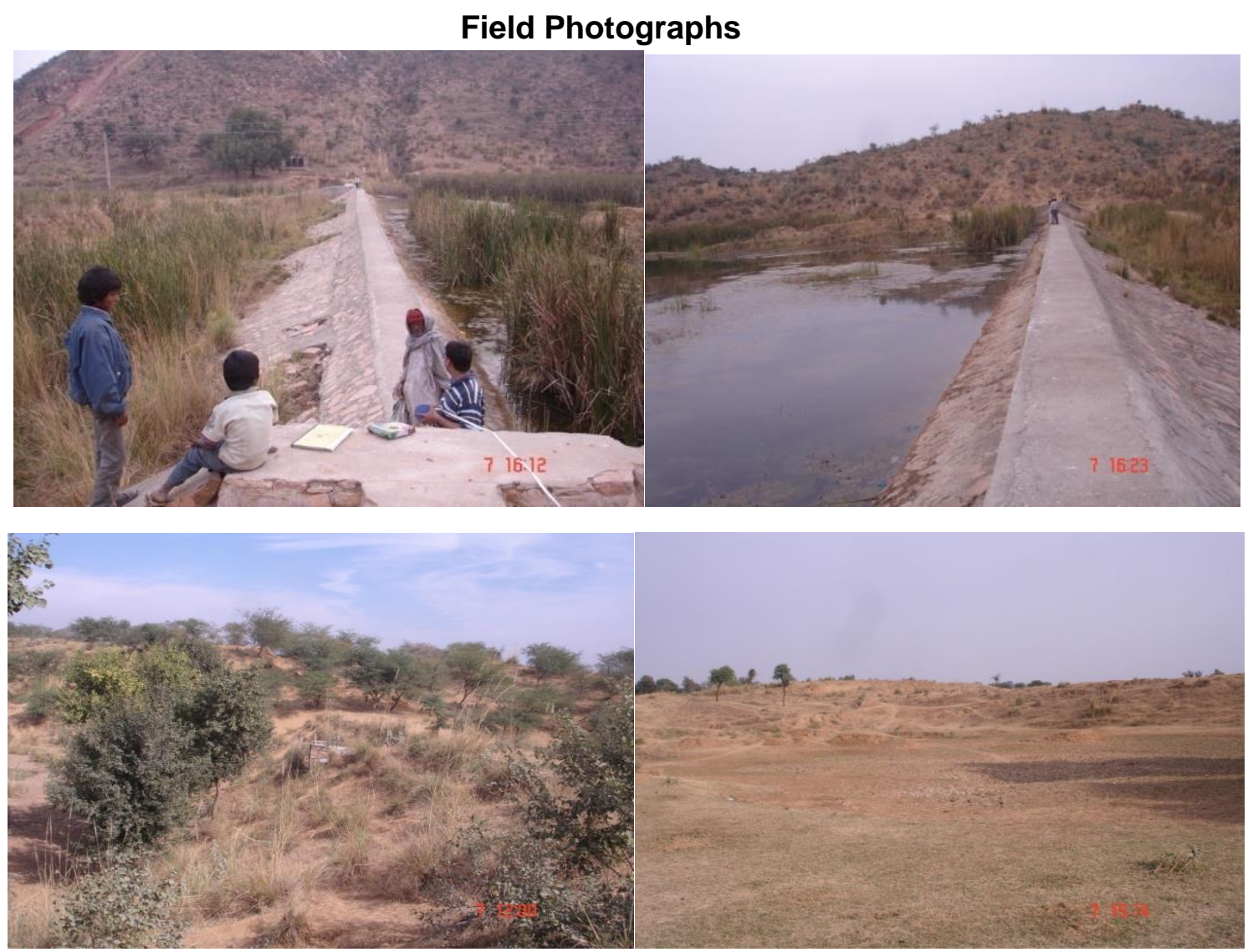

Medium Hydrological Structure

Minor hydrological structures are very small but are able to stop large quantity of water because they are constructed on $\mathrm{Ist}^{\text {st }}$ or $\mathrm{II}^{\text {nd }}$ order streams where small quantity of water is reached during rain or may be up to few minutes after actual rains. During gap in rains the water either percolate down or evaporates and these structures become dry and again they get water in next span of rain. This way these structures get water many times in a season and able to catch big amount of water during entire monsoon season. Therefore, these small structures are putting very effective check over runoff from their catchment. Minor structures have storage capacity of $19937.68 \mathrm{~m}^{3}$ against runoff $2203155.962 \mathrm{~m}^{3}$.

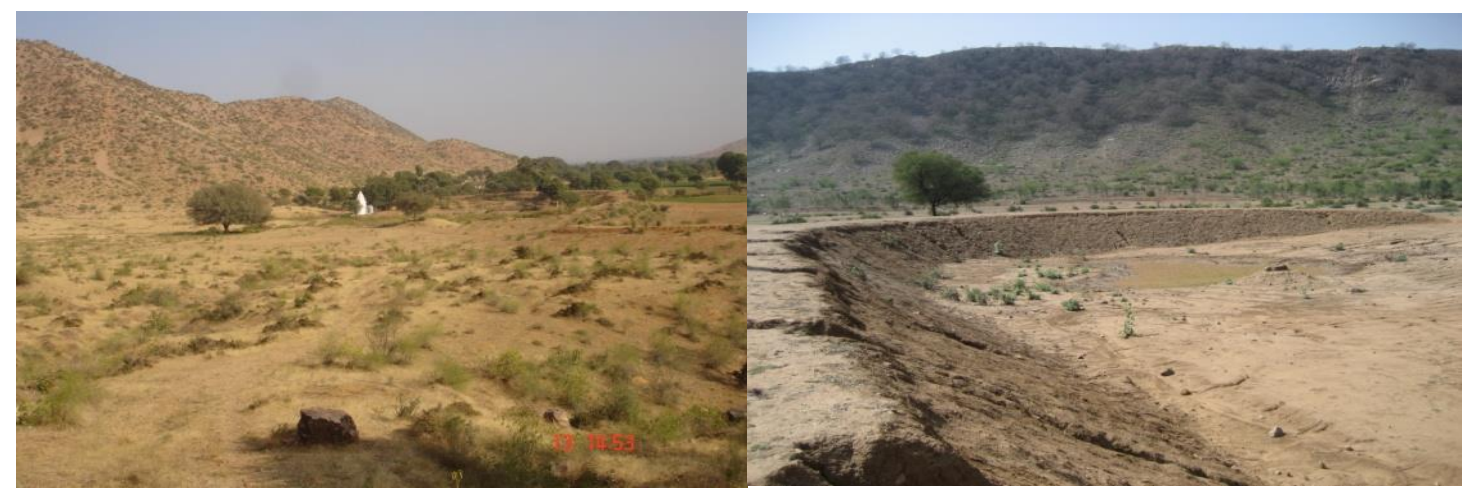

Minor Geological Structure 
Major hydrological structures can store the entire runoff generated from their catchments. (2259040.91) These structures are most affect the inflow of water into Ramgarh reservoir. Storage capacity of medium hydrological structures is $35447.39 \mathrm{~m}^{3}$ but due to limited number of rain days, when practically runoff is generated, these structures are able to catch $336662.39 \mathrm{~m}^{3}$ of water. Similarly, all 76 minor hydrological structures collectively can store $19937.68 \mathrm{~m} 3$ water at a time but practically they along with the micro structures (hundreds in number) can intercept huge amount of runoff $\left(2203155.96 \mathrm{~m}^{3}\right)$ during total monsoon season.

\section{Storage Capacity of Ramgarh Reservoir}

Water level data of 32 years have been analyzed. It is evident from data that up to year 1986 Ramgarh reservoir got good amount of water, when only few hydrological structures were constructed. During last 32 years water level reached to maximum capacity of 65 feet in year 1975. Thereafter it was never reached to the maximum capacity. During 1985 there was good rains during June, July and August months and the water level was reached to 62 feet. During 1987 because rainfall was abnormally low during these months and as a result water level come down to 27 feet and 9 inches only, which has again raised during 1988-89 due to good rains. Water level observed very low in drought years of 1990, 1991 which was 17' 10" and 27' 8.5" respectively. Period 1992-98 was experienced normal rains and water level was remains at medium level between 37 to 49 feet. After 1998 water level decreased sharply and could not come up because most of the structures are constructed after year 1997 through watershed development programs launched by Department of Forest and Department of Watershed and Soil Conservation. During 2003 there was abnormally high rainfall $(1068 \mathrm{~mm})$ but water level in Ramgarh dam could reach only up to 37 ' 8 '. Thereafter the reservoir is dried except during rainy season, and then dried completely.

\section{Conclusion}

The study shows that Jamwa Ramgarh Reservoir catchment has good runoff potential. According to the current study 4.799 million cubic meter (167.965 mcft.) runoff is generated from the catchment but 104 hydrological structures constructed across drainage channels has stopped the runoff to reach the water to the reservoir. This amount of water if reached to Jamwa Ramgarh reservoir it is sufficient to fill this reservoir up to $32 \mathrm{ft}$. height and can support to meet the water demand of Jaipur city in sustainable manner. Apart from 104 listed hydrological structures there are hundreds of micro structures available in the catchment area but they are so small that their storage capacities are negligible but able to stop process of runoff generation from tail ends of $1^{\text {st }}$ order streams. Due to these micro structures triggering of runoff is affected from many ends, which has resulted into considerable reduction in runoff generation.

\section{References}

1. Ashish Pandey and A.K. Sahu (1985). Dept. of Agriculture Engineering North Eastern Regional Institute of Science and Technology, Generation of curve number using Remote Sensing and GIS. Brace, Jovanovich Publishers, Orlando, USA.

2. Binau Kumar Singh (Sr. Scientist) BIT Mesra Extension Center Jaipur, Wasteland mapping of Ramgarh Lake Catchment by Remote Sensing \& GIS technique

3. C.F. Tolman (1937). Groundwater, McGraw Hill, New York.

4. C.P. Lo (1986). Applied Remote Sensing, Longman Scientific and Technical, U.K.

5. C. Sorrel, P.E. (2003). Michigan department of engineering quality Geological and land management division July (2003). Computing flood discharges for small ungaged watersheds

6. D.K. Todd (1980). Groundwater Hydrology, John Wiley.

7. E.T. Engman and R.J. Gurney (1981). Remote Sensing in Hydrology, Chapman and Hall, London. 
8. George Joseph, Fundamentals Of Remote Sensing by Universities Press (India) Limited

9. H.M. Raghunath (1987). Groundwater, Wiley Eastern.

10. Hong-Yuan Lee, M.ASCE; Ying-Tien Lin, and Yu-Jia Chiu J. (2006). Hydrologic Eng., Volume 11, Issue 4, pp. 362-370 (July/August 2006) Dept. of Civil Engineering and Hydraulic Research

11. H.S. Chen (1985). Space Remote Sensing Systems? An Introduction, Academic Press Inc. Harcourt Brace, Jovanovich Publishers, Orlando, USA.

12. K.D. Sharma and Surendra Singh [CAZRI), Jodhpur Runoff estimation using Landsat Thematic Mapper data and the SCS model.

13. K.R. Karanth (1989). Hydrogeology, Tata McGraw Hill.

14. K. Subramanyam, Engineering Hydrology Second edition.

15. Laboratory, National Taiwan Univ., Taipei, Quantitative Estimation of Reservoir Sedimentation from Three Typhoon Events.

16. Lillesand T M and Kieffer R W (1979). Remote Sensing and Image Interpretation, John Wiley, NY

17. Manual of Remote Sensing (1998). Principles And Applications Of Imaging Radar, ASPRS.

18. Nathanial Vandal Middlebury College, Using GIS to model runoff Time, Quantity and stream flow

19. Pratt William K (1978). Digital Image Processing, A Wiley inter Science Publication, New York.

20. P.A. Longley, D.J. McGuire, M.F. Goodchild and D. Rhind, GIS (Eds.) (1999). Principles and Applications, Longman.

21. P.A. Burroughs and R.A. McDonnell (Eds.) (1998). Principles of GIS, Oxford University Press.

22. P.B. Keith and Thompson (1974). Remote Sensing and Water Resources Management.

23. P.K. Singh Udaipur Watershed Management.

24. R.N. Colwell (Ed.) (1983). Manual of Remote Sensing, Vols. 1\&2, Second Edition, American Soc. of Photogrammetry, USA.

25. Robin T. Clarke (1994). Statistical Modelling in Hydrology; John Wiley \& Sons, England.

26. Richard J. Mandle, Michigan Department of Environmental Quality, Groundwater Modeling Program.

27. United States Department of Agriculture Technical Release 55 June 1986, Urban Hydrology for Small Watersheds.

28. Victor Mockus and Hydraulic engineer Estimation of direct runoff from storm rainfall. Richard.

29. Y, P, Parks \& A, Gustard Institute of Hydrology, Walling ford, Oxon OX10 8BB UK, A reservoir storage yield analysis for arid and semiarid climates. 